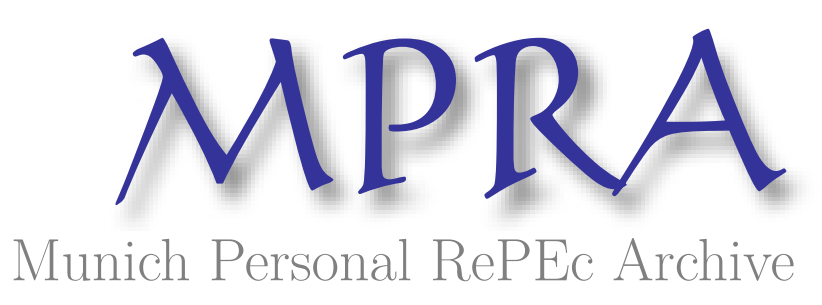

\title{
Advances and Issues in Fraud Research: A Commentary
}

Ozili, Peterson K

1 March 2018

Online at https://mpra.ub.uni-muenchen.de/84879/

MPRA Paper No. 84879, posted 04 Mar 2018 04:24 UTC 
Advances and Issues in Fraud Research: A Commentary

Peterson K Ozili

This Version: $1^{\text {st }}$ March, 2018 


\begin{abstract}
This article discusses some observations in the forensic accounting-based fraud literature. We identify recent advances in the literature and highlight several important issues that are worth noting. The main message of this commentary article is that fraud is complicated, and fraud complexity can significantly impact the way we undertake forensic accounting-based fraud research. The practical implication is that forensic accountants and forensic accounting researchers should incorporate into their practice the complexity of fraud regardless of whether they follow an empirical, experimental, exploratory, analytical or critical approach to fraud investigation.
\end{abstract}

Keywords: Fraud; Forensic Accounting; Fraud Detection; Financial Reporting; Data Mining; Forensic Accounting Education; Banking.

JEL Code: M41; M42; 


\section{Introduction}

According to the Association of Chartered Fraud Examiners (ACFE), fraud is defined as "the use of one's occupation for personal enrichment through the deliberate misuse or misapplication of the organization's resources or assets." Fraud has implications for investors, firm owners, regulators, auditors and the public around the world (Albrecht et al, 2008). Accounting (or financial) fraud has played a major role in the failure of many financial and non-financial institutions around the world. The negative publicity from the media towards firms that commit fraud continue to pose serious concern for the integrity of the audit profession and other supervisory bodies across several industries and puts pressure on fraud researchers to suggest solutions to deal with corporate and public fraud.

Fraud research can provide answers to some but not all questions regarding the complexity of fraudulent behaviour by individuals and organisations. One approach to understand the issues regarding fraud complexity is to begin from the simple issues to the complex ones. Accordingly, we highlight some factors that led to the growth in the fraud and forensic accounting literature, and also identify notable advances in the literature and the challenges that fraud pose to academic research and corporate practice and finally we suggest some direction for future research.

We commend prior review articles that examine fraud and forensic accounting practices, skills and certifications, and the need for forensic accounting education (e.g. Rezaee, 2002; Crumbley, 2009; Rezaee and Burton, 1997; Sharma and Panigrahi, 2013; Ozili, 2015, etc.). Building on these articles, this commentary article elaborates on some fraud themes in the forensic accounting literature that academics and practitioners may find useful; and the remarks, issues and directions for future research we provide in this commentary are not intended to be comprehensive but instead are limited to issues in the literature that we find to be particularly significant. While fraud is widely examined across several disciplines including the computing, business ethics and forensic science disciplines, fraud research in the field of forensic accounting is relatively emerging. Our study focusses on fraud research in the forensic accounting literature which is our main contribution to the literature. This commentary contributes to the forensic accounting literature on fraud research by identifying pertinent issues that academics and practitioners should take into account in their evaluation of the incidence of corporate fraud in their forensic accounting analyses or practices.

The remainder of this paper is organised as follows. Section 2 present factors that led to significant growth in the literature. Section 3 present some advances in the literature. Section 4 briefly identifies some challenges and proposes some possible direction for further research. Section 5 provides some concluding remark. 


\section{Growth in the Fraud and Forensic Accounting Literature}

Forensic accounting and fraud research has grown over the past two decades. One factor that contributed to the growth in fraud research was the collapse of large US companies that engaged in fraudulent accounting-based corporate governance practices such as Enron, WorldCom and Tyco, including a Big-5 audit firm Arthur Anderson (Rezaee, 2004; Ball, 2009; Huber, 2012). Interestingly, a Big 5 audit firm, Arthur Anderson, helped Enron commit accounting fraud. In search for huge profits, Arthur Anderson played down its high audit standards while seeking huge profits and as a result faced the consequences of its actions. Subsequently, several fraud revelations emerged during the period which has changed the corporate governance structure of firms around the world in recent years, which also led to greater demand for the services of forensic accountants and fraud investigators.

Another factor that encouraged the growth in forensic accounting research is the lack of in-depth forensic accounting education in the accounting curriculum in tertiary institutions compared to the greater emphasis and importance placed on other accounting topics in the accounting curriculum. Two decades ago, forensic accounting education was almost non-existent in the accounting syllabus of many tertiary institutions while much emphasis was placed on financial accounting, management accounting and auditing education. Rezaee (2002), Crumbley (2009) and Ozili (2015) provide an extensive review on forensic accounting education.

Another factor that encouraged the growth in forensic and fraud research is lack of confidence among investors about the reliability of information disclosed in the financial reports of large and complex organizations. The more complex the operations of large firms, the more difficult it is to detect financial and non-financial fraud once it has been committed, and the greater the need for the services of forensic accountants or investigators to help companies expose fraud hidden in accounting numbers and to trace fraud to the perpetrator.

Another factor is the growing number of white collar fraud committed by top executives of companies (Zahra et al, 2005). The increasing awareness that senior managers withhold information or give misleading information to obtain monetary benefits has been a motivation for studies investigating employee and top management fraud (Daboub et al, 1995), and this issue remain a highly debated topic today.

Another factor is the failure and inadequacy of internal auditing systems to detect top management fraud in firms (Sharma and Panigrahi, 2013). Another factor is the imperfection of the audit process. Because auditing is imperfect, there is the argument that the analytical procedures employed by auditors to detect unusual trends in financial ratios are often ineffective, and auditors' awareness of the ineffectiveness of these procedures have increased their over-reliance on management explanations to affirm the reliability of financial statement estimates (see. Anderson and Koonce, 1995; 
Hirst and Koonce, 1996; Bierstaker et al, 1999; Erickson et al, 2000; Bell et al, 2005). Also, more recently, there are growing concern that firms that engage in complex activities or sell complex products, such as investment banks, have substantial amount of information about the products they offer but disclose little information about their products to their clients, thereby misleading clients to enter into a transaction with little information and then claim that the client had a choice to opt out of the transaction if they felt they had insufficient information regarding the terms of the contract underlying the transaction. For instance, US firms such as Goldman Sachs, Citigroup, J.P Morgan to mention a few, were guilty of this behaviour and had to make out-of-court settlements to clients which they misled (see SEC report, 2015)', and the prevalence of such practices has also motivated fraud research in recent years. A final factor motivating forensic accounting research is the availability of financial data for firms that have some fraud history. The availability of data on fraud history makes it possible to verify and compare findings in the empirical literature. Data of firms that have a fraud history may be obtained directly from financial statements, or indirectly from SEC filings, thirdparty data providers and from other sources.

\section{Advances in Forensic and Fraud Research}

Recent advances in forensic accounting or fraud research may be divided into two broad categories. The first category focuses on fraud detection and prevention techniques by advocating the need for increased forensic accounting education among tertiary institutions. An extensive literature focus on forensic accounting education (e.g. Rezaee 2002; Crumbley, 2009; 0zili, 2015). The second category focus on fraud detection and prevention techniques by empirically investigating the financial report of firms that have a fraud history to observe whether unusual financial reporting patterns or trends can be detected.

It is important to stress that although fraud research is a wide and multidisciplinary literature, fraud research is not the same as forensic accounting research. Forensic accounting research investigates how accounting and non-accounting tools are employed to detect fraud patterns in the financial statements of companies and the effectiveness of such tools while fraud research on the other hand focus on the study of fraud motivations, types of fraud, the contexts in which fraud exist, institutional factors that encourage or discourage fraud, etc.

\subsection{Fraud Terminology}

One notable progress in the literature is the richness of fraud definition. There is no generally agreed definition of fraud in the literature; however, there are informative keywords or terminologies that are associated with the definition of fraud. For instance:

\footnotetext{
'http://www.sec.gov/spotlight/enf-actions-fc.shtml
} 
fraud is an 'intentional', 'deliberate', 'purposeful act', 'omission', 'disclosure of less information', 'misrepresentation', 'non-disclosure of relevant information', 'to disguise', 'cheat', 'mislead investors' and 'deceive firm owners, regulators, and stakeholders' (Rezaee, 2005; Apostolou et al, 2000; Ozkul and Pamukcu, 2012; Ozili, 2015; etc.). These informative keywords have been used to describe fraud which is broadly an attempt by individuals, employees and firm managers to obtain pecuniary benefits that would not be obtained without taking such actions (Zahra et al, 2005; Ozili, 2015).

\subsection{Attribute of Fraudsters}

Traditional forms of fraud include embezzlement, insider trading, self-dealing, lying, non-disclosure of information corruption, and cover-ups (e.g. Moberg, 1997). Today, the way fraud is being perpetuated is changing due to the emergence of sophisticated technologies (i.e., techniques and tools) which fraudsters can exploit to hide every trace of fraud, therefore, it makes sense to say that the propensity or likelihood of individuals to commit fraud is positively related to available sophisticated technologies or selfconstructed systems that help fraudsters to get away with fraud or to hide fraud traces.

Another issue is the attribute that fraudsters possess. Academics and practitioners have not reached a consensus on the characteristics or attributes of fraudsters. Nonetheless, there appear to be some consensus among practitioners that fraudsters may be divided into two groups: the 'greater good oriented fraudster' and 'the scheming, self-centred fraudster' (Ramamoorti, 2008; Brody et al, 2012). The greater good oriented fraudsters are honest individuals who intentionally misrepresent financial numbers and justify their actions by claiming that their action is in the best interest of the company while the scheming and self-centred fraudster misrepresent financial numbers for their personal interests rather than in the

\subsection{Fraud Motivators and Inhibitors}

Also, several factors within firms have been identified to encourage fraud such as weak corporate governance structure in firms (see. Beasley, 1996; Abbott et al, 2000; Beasley et al, 2000; Farber, 2005; Agrawal and Chadha, 2005; Ramaswamy, 2005, 0zili and Uadiale, 2017, etc), misappropriation of assets (see. Omar et al, 2016), high executive compensation incentives (see. Johnson et al, 2005; Bergstresser and Philippon, 2006; Efendi et al, 2007; Peng and Röell, 2008), weak internal control systems (see. Bell and Carcello, 2000), corporate lobbying (see. McCarten et al, 2016) and lack of funding to acquire sophisticated fraud detection tools (see. Ernst \& Young, 2010). Regarding lack of funding, substantial funding cuts in the fight against fraud can compel auditors and regulators to choose the least effective tools to help them detect fraud.

Factors within firms that discourage and prevent fraud include: strong internal auditors, enhanced audit committees and improved internal controls (see. Asiedu \& Deffo, 2017), fraud risk awareness (see. Eutsler et al, 2016), anti-fraud environment (see. Fleming et al, 2016), implementing fraud reporting policies, staff job rotation, fraud 
hotlines and the use of forensic accountants (see. Othman et al, 2015; Ozili, 2015) among others.

\subsection{Detecting Fraud}

\subsubsection{Non-financial measures}

Non-financial measures, although largely ignored, can be useful in fraud detection. Fraud can be detected by identifying unusual trend and pattern in non-financial measures of firm performance (e.g. Bell et al, 2005; Brazel et al, 2009). Bell et al (2005) point out that some non-financial measures (NFMs) of firm performance are more easily manipulated than others and Brazel et al (2009) suggest that NFMs are easily manipulated because NFMs may be ignored by auditors who pay much attention to financial measures of firm performance. Therefore, it is important for forensic accountants and investigators to understand key non-financial measures of firm performance that could provide red-flags to detect fraud.

\subsubsection{Data mining}

Data mining techniques can provide positive prospects for fraud detection. Data mining involves importing firm data into a computer program or software specifically designed to detect unusual trend in data so that the information obtained from such systems or software can provide useful tips to identify actual fraud and to identify the perpetrator. Data mining techniques are a proven method to identify unusual trends in current and past data in large databases (Clayton et al, 2006; Brown et al, 2007) and data mining techniques are strongly advocated by forensic scientists, not forensic accountants. However, while data mining comes with many advantages, the main disadvantage of this approach to auditors and forensic investigators is that the data mining programs or software are often expensive to purchase, costly to maintain and may require specialised computer skills or knowledge to operationalise such system throughout the company. See $\mathrm{Ngai}$ et al (2011) for an extensive of review of data mining as a fraud detection method.

\subsubsection{Interviews}

Another technique to detect fraud is the use of interviews. Interviews can be used to detect fraud and to obtain the admission of guilt by the person(s) accused of committing fraud while detailed document reviews may be used to complement interviews (see. Miller and Marston, 2006; Clayton, 2006). When fraud has been committed in a firm and there is suspicion due to unusual pattern in financial records, the person responsible for preparing the financial record is summoned for questioning via interview and such questioning can either lead to the admission of guilt or denial of any wrong-doing by the individual. Interviews are widely used in empirical fraud research. Empirical fraud researchers extensively use interviews to elicit response from interviewees to identify fraud and factors associated with fraudulent practices. 


\subsubsection{Stakeholders}

Stakeholders can play a significant role in fraud detection and there is evidence that firm stakeholders can detect corporate fraud. Dyck et al (2010) show that firm stakeholders are powerful whistle-blowers against fraud and can provide useful information to help investigators detect fraud when there are monetary benefits to serve as a reward for whistleblowing. This is interesting because external stakeholders can reveal fraud that may not be immediately visible to external auditors. Also, to the extent that firm stakeholders are market-based institutions, Dyck et al (2006) show that market-based institutions can also play a significant role in monitoring firms than regulatory-based institutions.

\subsubsection{Skill-set of Forensic Accountants}

Undoubtedly, the skills of the forensic investigator (or accountant) can contribute to any fraud detection activity. Boritz et al (2008) and Ozili (2015) demonstrate that the skill-set of the forensic accountant is important in the fraud detection process. Bierstaker et al (2006) show that while forensic accounting skills can aid the fraud detection process, the skill of a forensic accountant can be a least preferred method used by firms to detect actual fraud. In fact, Ramazani and Refiie (2010) observe that firms have low perception about the relevance of forensic accountants in the corporate structure of the organisation. Unsurprisingly, Ernst and Young (2003)'s worldwide fraud survey document that only $20 \%$ of firms employ the services of forensic accountants, and an explanation for this observation is that expert forensic accountants do not have a regular function in organisations compared to traditional internal auditors and financial (or management) accountant, which makes it difficult to permanently fit forensic accountants within the structure of an organisation. In the event of fraud suspicion, organisations are more likely to rely on their internal audit function to detect fraud and will hire forensic accountants and fraud examiners only as a last resort if the fraud detection outcome of the internal audit unit is unsatisfactory to shareholders and stakeholders of the organisation.

Usually, fraud detection skills of forensic accountants are obtained from extensive knowledge and training in forensic accounting education and/or practice which typically begins with identifying possible red-flags of fraud (Ozkul and Pamukc, 2012; Ozili, 2015). Fraud detection skills can also be improved by obtaining sound knowledge about how managers manipulate financial statement variables (Dechow et al, 1996; Beneish, 1997; Summers and Sweeney, 1998; Lee et al, 1999; Marquardt and Wiedman, 2004; McVay, 2006). 


\section{Issues}

\subsection{Good Data vs Manipulated Data}

One way to empirically test for unusual fraud pattern is to examine the data trend in the financial statement of companies that have been indicted with fraud. While this approach is common and logical, it is fraught with the problem of "reaction bias". Reaction bias is a situation where actor(s) or firms change their behaviour quickly to lessen the perceived consequence of their wrong doing. For instance, a firm indicted with fraud allegations can quickly alter and manipulate the records of the company to minimise the legal cost arising from their fraudulent behaviour. If firms alter their records when they are about to be indicted for fraud, then there will be concerns about the credibility of the financial information of the firm when such information is used to test for the existence of unusual fraud pattern.

In the case of corporate fraud, for instance, when a manager realise that a criminal lawsuit has been filed against the firm or will be filed against the firm in the near future, the manager will consider the possible legal costs. If the manager perceives that the legal cost will be too high, the manager will have some incentive to restructure the company records, ex-ante, in a way that lowers the legal cost that will be paid than would have been paid if the records were not adjusted. This ad-hoc restructuring of company records tends to give rise to unusual trends in financial and non-financial ratios and estimates in financial reporting before litigation. Therefore, any statistical analyses of the records of such firms by the empirical researcher can pick-up or detect these unusual trends which are mainly 'cover-up tactics' not the actual 'fraud pattern' the researcher or investigator want to find. These restructured company records in a sense reflect 'manipulated data', and the empirical researcher may confuse 'cover-up patterns' with 'actual fraud patterns' during statistical analyses, and this kind of manipulated data is a serious challenge in fraud research. From an econometric standpoint, taking a one or two-year lag of data prior to fraud litigation date can help eliminate or reduce the 'reaction bias' problem in fraud data when analysing the financial statements of firms.

This problem is also common with the use of interviews because the interviewee can provide over-exaggerated or untrue interview-response about a company depending on how the company treats the interviewee who may be a current employee that wants to defend the company or an employee that was fired who wants to seek revenge against the company. Whichever is the case, the interviewee's response is likely to be biased and, in a sense, reflect 'manipulated truth' or manipulated information (data). The investigator may confuse 'over-exaggerated or untrue interview-response' with the truth, and this kind of manipulated information often pose a serious challenge in fraud research. In reality, because 'good data' and 'manipulated data' can exist in different forms, it can be difficult to understand whether the data used in empirical fraud studies is 'good data' or 'manipulated or window-dressed data'. The need for good data. Levitt 
and Dubner (2005) confirm that one reason why academics know very little about the practicalities of fraud is the paucity of good data.

\subsection{Fraud and Morality}

The ability to attach a convincing and moral explanation to justify fraudulent behaviour is often the distinct characteristic of the lucky fraudster from the unlucky fraudster. Willott et al (2001) show that fraudsters who commit white-collar crime claim that they felt justified in committing fraud to save their company, their jobs, and other businesses that relied on the survival of the company. Employees that commit fraud to save their company are more likely to feel good about their plans to defraud because it is for the greater good of oneself and the company, and this potentially explain why the number of white-collar fraudsters increases year by year despite employees' awareness of the legal consequences of engaging in fraudulent activities or behaviour. For example, bank traders that trade in complex securities and derivative products often take irrational actions and conceal relevant information to outperform their counterparties in the market in order to obtain massive profits that benefit the company and themselves. Another obvious example is the 2008 global financial crisis. At the heart of the 2008 global financial crisis, many too-big-to-fail financial institutions deliberately stopped lending to other firms that relied on their lending, and this initiated large-scale loan default across several businesses that relied on the too-big-to-fail financial institutions. The subsequent interrogation of the CEOs of these too-big-to-fail financial institutions during the $\mathrm{FCIC}^{2}$ interview panel show that the CEOs believed that their action (to stop lending) was intended to serve a greater moral good which was, partly, to prevent the entire collapse of their own firm during the crisis. Surprisingly, not a single CEO of the too-big-to-fail financial institutions went to jail for failing to lend during the crisis, even though it was a clear breach of their contractual obligation to lend. The CEOs were vindicated because they provided a moral justification for doing so.

In a nutshell, if a fraudster believes that committing fraud will fulfil a higher moral good, the fraudster will have strong incentive to commit fraud that achieves that moral good. At worse, in a court of law, fraudsters that have strong moral intent behind the fraud they commit are more likely to receive lesser penalty than fraudster with no convincing moral intent. Therefore, the morality of fraud is a concern that academics should not ignore in forensic accounting (and fraud) research.

\footnotetext{
${ }^{2} \mathrm{FCIC}$ denote 'Financial Crisis Inquiry Commission'. The report is available here: http://cybercemetery.unt.edu/archive/fcic/20110310173538/http://www.fcic.gov/report
} 


\subsection{Fraud and Legality}

Fraud can be perpetuated as a legitimate activity when there is no clear-cut distinction between legal and illegal behaviour due to complicated laws and regulations. Intelligent or smart fraudsters are more likely to engage in fraudulent activities that are intertwined with legitimate activities to take advantage of complicated laws and regulations that do not make a clear distinction between legal and illegal behaviour. For instance, Brody (2012) notes that when illegal and legal acts occur concurrently, the job of the forensic investigator becomes difficult because legal rules are often used by fraudsters to justify their illegal and fraudulent behaviour.

Also, complicated laws that are enacted to protect a group of stakeholders may create fraudulent opportunities for another group of stakeholders. Berenson (2003) argue that laws and regulations enacted to protect shareholders' interests can become so complicated that they contribute to the growing incidence of top managerial fraud. The implication of Berenson (2003)'s argument is that complicated laws and regulations that discourage a group of fraudsters can have the unintended consequence of encouraging another group of fraudsters that seek to exploit loop-holes in complicated laws to commit fraud, and this is an issue that has not been extensively explored in the forensic accounting and fraud literature.

\subsection{Fraud Research in Banks}

Many studies investigate forensic accounting and fraud detection practices among firms with little focus on banks. Very few studies examine fraud in banks from a forensic accounting perspective. For instance, Rahman et al (2014) using surveys show that some bankers perceive that software data protection is more effective in dealing with bank fraud. One reason for the limited investigation into bank fraud in fraud research is due to the opacity of bank activities. The opacity of a bank reflects the opacity of the industry to which it belongs. The banking industry is a relatively less transparent industry and banks' financial reporting is less transparent and is poised to remain so for a long time (Beatty and Liao, 2014), therefore, the opacity of bank activities is an explanation for the paucity of fraud research involving banks. While this explanation seems valid, this argument is criticised because it limits the usefulness of forensic accounting to the banking sector because if fraud in banks is difficult to detect due to opaque bank financial reporting, then it will be more difficult to stop bank fraud perhaps until angels become bank managers.

Moreover, the scant research into bank fraud by forensic accounting (and fraud) researchers raise serious concern about the contribution of forensic accounting (and fraud) research to banking practice. Banks should not be ignored because the findings from non-banking institutions cannot be generalised to banks because banks are unique. Rather than ignoring banks, forensic accounting (and fraud) research involving banks should be encouraged because the findings from bank-related forensic 
accounting (and fraud) research can make a valuable contribution to the banking literature and to banking practice if it can provide substantial insight to detect fraud in banks. While fraud detection in banks is not a straightforward process due to several factors that work together to make fraud detection difficult in banks, the contribution of forensic accounting to banking practice is very much needed. A fruitful starting point is to identify and discuss several factors that contribute to the difficulty of forensic accounting practice among banks and financial institutions.

\subsection{Suggestions for Future Research}

Regarding the morality and legality of fraud discussed in 4.2 and 4.3, some questions need to be addressed. For instance, as academics and fraud investigators, what should we focus on. Should forensic accounting-based fraud research focus on companies and individuals that have been reported and/or indicted for fraud? Or, should we focus on individuals and/or companies that have pleaded guilty to fraud claims simply because they do not have a convincing moral and legal justification for their actions? Should we exclude super-smart individuals and corporate fraudsters that won their fraud inquiry panel and escaped prosecution because the fraud they perpetuated served a higher moral good? Should we ignore and remain silent about complicated laws and regulations that create incentives to commit fraud? We need more answers! Academics do not have all the answers, but we can provide some answers.

Regarding fraud networks, Karwai (2002) report that identifying the causes of fraud is difficult because modern-day organisational fraud usually involves a complex web of conspiracy and deception that often mask the actual cause of fraud, implying that there is a network of fraud or fraud network. To date, there is scant research into fraud networks in the forensic accounting literature; therefore, an investigation into fraud networks is needed. Moreover, because fraud networks involve social agents, an investigation into fraud networks from a sociological agent-based network perspective will be useful.

Finally, future studies can attempt to develop models that can predict firms that are more likely to commit fraud before the fraud is committed. Some academics consider this to be the holy grail of empirical forensic accounting research. If we can achieve this, the knowledge and skills of forensic accountants and investigators will become more relevant to industry regulators around the world. 


\section{Concluding Remark}

This article provides a concise commentary on some advances and issues in forensic accounting-based fraud research. We observe that academic inquiry into the field of fraud research is growing and the knowledge of forensic accounting can support fraud detection activities. However, data mining techniques and other tools developed from forensic science research has limited usefulness to forensic accounting practice due to huge cost, complexity and skill concern. We identified some interesting advances and issues in the literature and provide some direction for future research. The issues we highlight in this commentary show that fraud is complicated, and fraud complexity can significantly influence the empirical and non-empirical findings from forensic accounting-based fraud research; therefore, forensic accountants and investigators need to incorporate into their practice the complexity of fraud regardless of whether they follow an empirical, experimental, exploratory, analytical or critical approach to fraud investigation.

\section{Reference}

Abbott, L.J., Park, Y. and Parker, S. (2000), The effects of audit committee activity and independence on corporate fraud, Managerial Finance, 26, 11, 55-68.

Agrawal, A. and Chadha, S. (2005), Corporate governance and accounting scandals", Journal of Law and Economics, 48, 371-406.

Albrecht, W., Albrecht, C., Albrecht, C. and Zimbelman, M. (2008), Fraud examination, Cengage Learning.

Anderson, U.L. and Koonce, L. (1995), Explanation as a method for evaluating clientsuggested causes in analytical procedures, Auditing, 14, 2, 124.

Apostolou, B.A., Hassell, J.M., Webber, S.A. and Sumners, G.E. (2001), The relative importance of management fraud risk factors, Behavioral Research in Accounting, 13,1, $1-24$.

Ball, R. (2009), Market and political/regulatory perspectives on the recent accounting scandals, Journal of Accounting Research, 47, 2, 277-323.

Beasley, M. (1996), An empirical analysis of the relation between the board of director composition and financial statement fraud, The Accounting Review, 71, 443-465.

Beasley, M.S. (2000), Fraud-related SEC enforcement actions against auditors: 19871997, The Institute. 
Beatty, A., \& Liao, S. (2014). Financial accounting in the banking industry: A review of the empirical literature. Journal of Accounting and Economics,58, 2, 339-383.

Bell, T.B., Peecher, M. and Solomon, I. (2005), The 21st Century Public-Company Audit: Conceptual Elements of KPMG's Global Audit Methodology, Montvale, NJ: KPMG.

Bell, T.B. and Carcello, J.V. (2000), A decision aid for assessing the likelihood of fraudulent financial reporting, Auditing: A Journal of Practice \& Theory, 19, 1, 169-184.

Beneish, M.D. (1997), Detecting GAAP violation: Implications for assessing earnings management among firms with extreme financial performance, Journal of accounting and public policy, 16, 3, 271-309.

Berenson, A. (2003), A US Push on Accounting Fraud, New York Times, April, 9.

Bergstresser, D. and Philippon, T. (2006), CEO incentives and earnings management, Journal of financial economics, 80, 3, 511-529.

Bierstaker, J.L., Bedard, J.C. and Biggs, S.F. (1999). The role of problem representation shifts in auditor decision processes in analytical procedures, Auditing: A Journal of Practice \& Theory, 18, 1, 18-36.

Bierstaker, J.L., Brody, R.G. and Pacini, C. (2006). Accountants' perceptions regarding fraud detection and prevention methods, Managerial Auditing Journal, 21, 5, 520-535.

Boritz, J.E., Kotchetova, N. and Robinson, L.A. (2008). Planning fraud detection procedures: Forensic accountants vs auditors, In IFA conference, accessed $14^{\text {th }}$ December 2015.

Brazel, J.F., Jones, K.L. and Zimbelman, M.F. (2009), Using nonfinancial measures to assess fraud risk, Journal of Accounting Research, 47, 5, 1135-1166.

Brody, R.G., Melendy, S.R. and Perri, F.S. (2012), Commentary from the American Accounting Association's 2011 annual meeting panel on emerging issues in fraud research, Accounting Horizons, 26, 3, 513-531.

Brown, A., Aiken, P. and Visser, L. (2007), Reducing Fraud: A Programme to Deliver Benefits on the Bottom Line, Accountancy Ireland, 39, 6, 28.

Clayton, M.M. (2006), Investigative Techniques. In A Guide to Forensic Accounting Investigation edited by Golden, in Thomas W., Skalak, Steven L., and Mona M. Clayton, pp. 295-311, Hoboken, NJ: John Wiley \& Sons. Inc.

Crumbley, D.L. (2009), So what is forensic accounting? The ABO Reporter.

Daboub, A.J., Rasheed, A.M., Priem, R.L. and Gray, D. (1995), Top management team characteristics and corporate illegal activity, Academy of Management Review, 20, 1, 138-170. 
Dechow, P.M., Sloan, R.G. and Sweeney, A.P. (1996), Causes and consequences of earnings manipulation: An analysis of firms subject to enforcement actions by the sec, Contemporary accounting research, 13, 1, 1-36.

Dyck, A., Morse, A. and Zingales, L. (2006). The nature of corporate fraud, Working Paper, University of Chicago.

Dyck, A., Morse, A. and Zingales, L. (2010), Who blows the whistle on corporate fraud?, The Journal of Finance, 65, 6, 2213-2253.

Efendi, J., Srivastava, A. and Swanson, E.P. (2007), Why do corporate managers misstate financial statements? The role of option compensation and other factors, Journal of Financial Economics, 85, 3, 667-708.

Erickson, M., Mayhew, B.W. and Felix, W.L. (2000). Why do audits fail? Evidence from Lincoln Savings and Loan, Journal of Accounting Research, 165-194.

Ernst \& Young. (2003). Fraud: Unmanaged risk. 8th global survey, Global investigations dispute advisory services, South Africa.

Ernst \& Young. 2010. Driving ethical growth - New markets, new challenges. 11th Global Fraud Survey. Available online at http://www.ey.com/Publication/vwLUAssets/Driving_ethical_growth_new_markets,_new_challenges:_11th_Global_Fraud_Survey/\$FILE/EY_11th_Global_Fra ud_Survey.pdf, retrieved June 18, 2013

Eutsler, J., Nickell, E. B., \& Robb, S. W. (2016), Fraud Risk Awareness and the Likelihood of Audit Enforcement Action, Accounting Horizons, 30, 3, 379-392.

Farber, D.B. (2005), Restoring trust after fraud: Does corporate governance matter? The Accounting Review, 80, 2, 539-561.

Fleming, A. S., Hermanson, D. R., Kranacher, M. J., \& Riley, Jr, R. A. (2016), Financial Reporting Fraud: Public and Private Companies, Journal of Forensic Accounting Research. 1, 1, A27-A41.

Hirst, D.E. and Koonce, L. (1996), Audit analytical procedures: A field investigation, Contemporary Accounting Research, 13, 2, 457-486.

Huber, D.W. (2012), Is Forensic Accounting in the United States Becoming a Profession? Journal of Forensic and Investigative Accounting, 4, 1, 255-283

Karwai, S.A. (2002), Bank Fraud: Can Shariah prevent it?, Journal of Business Administration, 2, 1, 62-78.

Lee, T.A., Ingram, R.W. and Howard, T.P. (1999). The Difference between Earnings and Operating Cash Flow as an Indicator of Financial Reporting Fraud, Contemporary Accounting Research, 16, 4, 749-786. 
Levitt, S.D., and Dubner, S.J. (2005). Freakonomics: A rogue economist explores the hidden side of everything, New York, NY: William Morrow.

Marquardt, C.A. and Wiedman, C.I. (2004), How are earnings managed? An examination of specific accruals, Contemporary Accounting Research, 21, 2, 461-491.

McCarten, M., Diaz-Rainey, I., Roberts, H., \& Tan, K. M. (2016). Corporate Lobbying and Fraud Detection: Revisited. Available at SSRN: https://ssrn.com/abstract=2647829

McVay, S.E. (2006). Earnings management using classification shifting: An examination of core earnings and special items, The Accounting Review, 81, 3, 501-531.

Miller, F.R., and Marston, D.L. (2011), “Building a Case: Gathering and Documenting Evidence", A Guide to Forensic Accounting Investigation, pp. 175-189.

Moberg, D.J. (1997). On employee vice, Business Ethics Quarterly, 7, 4, 41-60.

Ngai, E.W.T., Hu, Y., Wong, Y.H., Chen, Y. and Sun, X. (2011). The application of data mining techniques in financial fraud detection: A classification framework and an academic review of literature, Decision Support Systems, 50, 3, 559-569.

Omar, M., Omar, M., Nawawi, A., Nawawi, A., Puteh Salin, A. S. A., \& Puteh Salin, A. S. A. (2016). The causes, impact and prevention of employee fraud: A case study of an automotive company, Journal of Financial Crime, 23, 4, 1012-1027.

Othman, R., Aris, N. A., Mardziyah, A., Zainan, N., \& Amin, N. M. (2015), Fraud Detection and Prevention Methods in the Malaysian Public Sector: Accountants' and Internal Auditors' Perceptions, Procedia Economics and Finance, 28, 59-67.

Ozili, P.K. (2015), “Forensic accounting and fraud: A review of literature and policy implications", International Journal of Accounting and Economics Studies, 3, 1, 63-68.

Ozili, P. K., \& Uadiale, O. (2017). Ownership concentration and bank profitability. Future Business Journal, 3, 2, 159-171.

Özkul, F.U. and Pamukçu, A. (2012). Fraud Detection and forensic accounting, Emerging Fraud, Springer Berlin Heidelberg, pp.19-41.

Peng, L. and Röell, A. (2008), Executive pay and shareholder litigation, Review of Finance, 12, 1, 141-184.

Rahman, R. A., \& Anwar, I. S. K. (2014). Effectiveness of fraud prevention and detection techniques in Malaysian Islamic Banks. Procedia-Social and Behavioral Sciences, 145, 97-102.

Ramamoorti, S. (2008). The psychology and sociology of fraud: Integrating the behavioral sciences component into fraud and forensic accounting curricula, Issues in Accounting Education, 23, 4, 521-533. 
Ramaswamy, V. (2005). Corporate governance and the forensic accountant, The CPA Journal, 75, 3, 68 .

Ramazani, M., and Rafiei, A.H. (2010), Iranian accountants' conception of the prevention methods of fraud and offering some recommendations to reduce fraud in Iran, Global Journal of Management and Business Research, 10, 6, 31-45.

Rezaee, Z. and Burton, E.J. (1997). Forensic accounting education: insights from academicians and certified fraud examiner practitioners. Managerial Auditing Journal, $12,9,479-489$.

Rezaee, Z. (2002), Forensic accounting practices, education, and certifications", Journal of Forensic Accounting 3, 2, 207-223.

Rezaee, Z. (2005). Causes, consequences, and deterrence of financial statement fraud", Critical Perspectives on Accounting, 16, 3, 277-298.

Sharma, A. and Panigrahi, P.K. (2013). A review of financial accounting fraud detection based on data mining techniques. arXiv preprint arXiv:1309.3944.

Summers, S.L. and Sweeney, J.T. (1998). Fraudulently misstated financial statements and insider trading: An empirical analysis, Accounting Review, 131-146.

Willott, S., Griffin, C. and Torrance, M. (2001). Snakes and Ladders: Upper-Middle Class Male Offenders Talk About Economic Crime, Criminology, 39, 2, 441-466.

Zahra, S.A., Priem, R.L. and Rasheed, A.A. (2005). The antecedents and consequences of top management fraud", Journal of Management, 31, 6, 803-828. 